\title{
The emerging role of genetics professionals in forensic kinship DNA identification after a mass fatality: lessons learned from Hurricane Katrina volunteers
}

\author{
Siobhan M. Dolan, MD, MPH ${ }^{1,2}$, Devki S. Saraiya, $M S^{3}$, Sandra Donkervoort, $M S^{4}$, Kelly Rogel, $M S^{2}$, \\ Caroline Lieber, MS, CGC $C^{2}$, and Amanda Sozer, $P h D^{5}$
}

\begin{abstract}
Purpose: To explore the experience of medical genetics professionals who volunteered in the DNA identification efforts after Hurricane Katrina to identify "lessons learned" and plan for future recovery efforts. Methods: A web-based survey was administered to volunteers in the Fall of 2007. Results: Sixty-six individuals (75\%) completed the survey. Eighty-six percent volunteered because they felt their skills as genetics professional were needed and $46 \%$ desired additional training on the molecular aspects of kinship analysis. Most (97\%) reported that they would like to see the genetics community become actively involved in further developing the role of genetics professionals in mass fatality response. All respondents (100\%) would volunteer again. Conclusion: Developing a registry of volunteers and educational materials tailored to the needs of genetics professionals should be explored as a mechanism to prepare the genetics community to play an active role in future mass fatality response. Genet Med 2009:11(6):414-417.
\end{abstract}

Key Words: DNA identification, mass fatality, emergency preparedness

In August 2005, Hurricane Katrina struck the Gulf Coast of the United States, causing massive destruction and flooding. It was one of the costliest and most destructive natural disasters with 13,197 individuals reported missing and an estimated 1,464 fatalities. ${ }^{1}$ In the wake of Hurricane Katrina, a Family Assistance Center (FAC) was established to assist families in identifying their loved ones who were victims of Hurricane Katrina. Run by the Louisiana Department of Health and Hospitals, the FAC had a broad multidisciplinary staff, which included paid staff and volunteers, many of whom worked on making victim identifications. The extent of the Katrina disaster was unique in that direct DNA identification, which was widely used in identifying victims after September 11 th, 2001, ${ }^{2}$ was not possible in many cases because DNA reference samples (e.g., personal items such as razors or toothbrushes) were destroyed in

From the ${ }^{1}$ Department of Obstetrics and Gynecology and Women's Health, Division of Reproductive Genetics, Albert Einstein College of Medicine/ Montefiore Medical Center, Bronx, New York; ${ }^{2}$ Joan H. Marks Graduate Program in Human Genetics, Sarah Lawrence College, Bronxville, New York; ${ }^{3}$ Clinical Cancer Genetics Program, University of Texas M. D. Anderson Cancer Center, Houston, Texas; ${ }^{4}$ Ken and Ruth Davee Department of Neurology and Clinical Neurological Sciences, Northwestern University Feinberg School of Medicine, Chicago, Illinois; and ${ }^{5}$ Sozer, Niezgoda and Associates, LLC, Alexandria, Virginia.

Siobhan Dolan, MD, MPH, Belfer 501, 1300 Morris Park Avenue, Bronx, NY 10461. E-mail: siobhanmdolan@yahoo.com.

Dr. Amanda Sozer was contracted by the Louisiana Department of Health and Hospitals to run the DNA identification unit at the Family Assistance Center in Baton Rouge, Lousiana, from December 2005 to June 2006.

Submitted for publication December 2, 2008.

Accepted for publication February 17, 2009.

Published online ahead of print May 13, 2009.

DOI: 10.1097/GIM.0b013e3181a16ccc the flooding. This resulted in a substantial number of cases in which victims of the Hurricane Katrina disaster could be identified only through kinship analysis. ${ }^{3}$

The role of genetics professionals in forensic kinship DNA identification after a mass fatality was initiated in response to recommendations of a multidisciplinary group advisory group (the Kinship and DNA Analysis Panel). The Kinship and DNA Analysis Panel was empanelled to assist the New York City Office of the Chief Medical Examiner and New York State Police DNA laboratories in the difficult and unprecedented legal and humanitarian challenges faced in the World Trade Center victim identifications. In kinship DNA identification, genetics professionals interact with families to determine which member is reported missing and then construct a pedigree identifying family members that could potentially provide a DNA sample to allow identification.

Kinship analysis entails gathering family history data and DNA samples from family members related to an individual reported missing to establish possible profiles for the missing individual. Identifications are made through matching DNA samples obtained from unidentified bodies with these possible genetic profiles. Accurate elicitation of family relationships and identification of informative family members is key to kinship analysis. Given that medical genetics professionals have the unique training and expertise needed to elicit accurate family relationships when individuals are potentially emotionally volatile, and the ability to identify family members that are informative for accurate kinship analysis, they are ideally suited to assist in DNA identification efforts. In addition, genetics professionals understand both the delicate nature of the information being requested and its possible psychological repercussions.

In late 2005 and early 2006, calls for volunteers for the FAC were made via listservs and through word of mouth in the medical genetics community, especially in the genetic counseling community. In total, 88 volunteers from 20 states and Canada, representing 43 institutions/practices went to the FAC in Baton Rouge to work with families to construct pedigrees for use in kinship analysis in the time period between December 2005 and June 2006. This was the first time that volunteers from the medical genetics field played a notable role in a DNA mass fatality recovery effort. Before arriving at the FAC, the volunteers participated in a teleconference where they received background information on the project. Once they arrived at the FAC they received hands-on training and supervision by forensic DNA scientists specializing in kinship analysis. The volunteers were provided written procedures as well as telephone and Internet access to locate individuals and reunite families as well as specific software for collecting ante mortem information from those that could not be located. Each volunteer was typically given approximately 20 cases to begin to process. As cases were resolved and as time permitted, the volunteers were given more cases. The forensic scientists helped the volunteers 
determine who to collect samples from based on the family members available and the forensic systems employed by the laboratories, which included autosomal short tandem repeats, short tandem repeats on the Y-chromosome, and mitochondrial sequencing. The volunteers were also able to link cases where related people were reported missing. Because of the efforts of the volunteers and others working at the FAC, the number of reported missing was reduced from approximately 13,000 down to about 150 when the DNA operations ended at the FAC in June 2006

We sought to follow-up with those volunteers who were instrumental in the DNA identification efforts and conducted a survey to gain insight into the experience and identify lessons learned. We hoped that the survey results would provide valuable information for medical genetics professionals and their professional societies to plan and prepare for future efforts.

\section{MATERIALS AND METHODS}

In total, 88 genetics professionals volunteered at the FAC in Baton Rouge in 2005-2006, working with emotionally distraught families to locate missing individuals so that DNA cases could be closed. Volunteers also elicited family history information so that appropriate family reference samples could be collected for DNA testing. As part of the experience, volunteers were offered a tour of affected areas in New Orleans.

A web-based survey exploring demographics, motivations for volunteering, and issues surrounding preparation, training, logistics, skills utilization, emotional response, overall experience, and future directions was administered in the Fall of 2007 to those genetics professionals who had worked at the FAC. Respondents were presented with a series of statements and were asked to respond on a 5-point Likert scale with the choices being (1) strongly agree, (2) agree, (3) neutral, (4) disagree, and (5) strongly disagree. Another set of questions asked respondents to rate issues on a scale of $1-5$ with 1 being most important and 5 being least important. At the end of each series of statements, an area was provided for respondents to add their own free form comments. The survey was e-mailed to the 81 Katrina volunteers for whom working email addresses were available and distributed via the listserv of the National Society of Genetic Counselors. Participation in the survey was entirely voluntary and all professionals contacted were provided with a statement outlining the nature of the request to participate, the time commitment, the voluntary nature of participation, and contact information for further information.

\section{RESULTS}

Sixty-six individuals, of the 88 who had volunteered, responded to the survey, representing a response rate of $75 \%$.

\section{Demographics (Table 1)}

A majority of respondents were women $(95.5 \%)$ and reported working full time $(82 \%)$. Most $(56.1 \%)$ were between the ages of 26 and 35, did not have any children (71.2\%), and were not married $(54.5 \%)$ at the time they went to Baton Rouge. Most volunteers had a masters degree $(68.2 \%), 54.6 \%$ had a bachelors degree, and $47 \%$ were certified genetic counselors. Two thirds of volunteers $(66.7 \%)$ were employed as genetic counselors, $25.8 \%$ were genetic counseling students, and $3 \%$ worked as clinical geneticists or genetics fellows. The principle field of practice was clinical $(69.4 \%)$ and work setting was a university hospital $(40.8 \%)$. Student volunteers were mostly full-time students $(87.5 \%)$.
Table 1 Demographics and practice setting of volunteers

\begin{tabular}{|c|c|}
\hline Characteristic & Total, $\%(\mathrm{n}=66)$ \\
\hline \multicolumn{2}{|l|}{ Gender } \\
\hline Female & $95.5(63)$ \\
\hline Male & $4.5(3)$ \\
\hline \multicolumn{2}{|l|}{ Age } \\
\hline$<25$ & $9.1(6)$ \\
\hline $26-35$ & $56.1(37)$ \\
\hline $36-45$ & $16.7(11)$ \\
\hline $46-55$ & $13.6(9)$ \\
\hline$>56$ & $4.5(3)$ \\
\hline Married & $45.5(30)$ \\
\hline \multicolumn{2}{|l|}{ Do you have children? } \\
\hline Yes & $28.8(19)$ \\
\hline No & $71.2(47)$ \\
\hline \multicolumn{2}{|l|}{ Primary employment } \\
\hline Clinical geneticist & $1.5(1)$ \\
\hline Genetic counselor & $66.7(44)$ \\
\hline Genetic counseling student & $25.8(17)$ \\
\hline Genetics fellow & $1.5(1)$ \\
\hline Other $^{a}$ & $4.5(3)$ \\
\hline Primary place of employment & $\%(n=49)$ \\
\hline University Hospital/Medical School & $44.9(22)$ \\
\hline Private Hospital/Medical Facility & $26.5(13)$ \\
\hline Federal Government & $12.2(6)$ \\
\hline Private Practice & $8.2(4)$ \\
\hline Public Hospital/Medical Facility & $4.1(2)$ \\
\hline Other $^{b}$ & $4.1(2)$ \\
\hline
\end{tabular}

\section{Motivation}

Ninety-two percent of respondents indicated that they volunteered at the FAC because it provided them with the opportunity to become personally involved in the recovery efforts after Hurricane Katrina. In addition, $86 \%$ volunteered because they felt their skills as genetics professional were needed. As one individual said, "It was the right thing to do."

\section{Preparation and training (Table 2)}

Before traveling to Baton Rouge, volunteers participated in a 3-hour conference call training session in which they were oriented to the computer system and basic workflow at the FAC. Although $62 \%$ of respondents indicated that they felt confident in their preparations before traveling to the FAC, it was reported that ". . . the best preparation for this type of experience is to learn on the job." Upon arrival at the FAC, volunteers received 
Table 2 Preparation and training

\begin{tabular}{|c|c|}
\hline & $\begin{array}{l}\text { Percent of respondents who } \\
\text { agree or strongly agree }\end{array}$ \\
\hline $\begin{array}{l}\text { I felt prepared for my role at the } \\
\text { FAC }\end{array}$ & 60.6 \\
\hline $\begin{array}{l}\text { My institution was supportive of me } \\
\text { going }\end{array}$ & 84.1 \\
\hline $\begin{array}{l}\text { I was confident in my capabilities to } \\
\text { complete the tasks that were } \\
\text { assigned to me }\end{array}$ & 77.2 \\
\hline $\begin{array}{l}\text { I felt that that the conference call } \\
\text { training prior to departure was } \\
\text { helpful }\end{array}$ & 62.3 \\
\hline $\begin{array}{l}\text { I believe that the on-site training } \\
\text { was helpful }\end{array}$ & 81.2 \\
\hline $\begin{array}{l}\text { I felt that the workload was } \\
\text { reasonable }\end{array}$ & 90.9 \\
\hline $\begin{array}{l}\text { I would have liked to have more } \\
\text { information on my tasks at the } \\
\text { FAC }\end{array}$ & 51.5 \\
\hline $\begin{array}{l}\text { I would have liked to have more } \\
\text { information on the background of } \\
\text { the kinship DNA identification } \\
\text { process }\end{array}$ & 45.4 \\
\hline
\end{tabular}

a 2 hour hands-on orientation in the DNA unit in which they were taken through an open missing persons case while learning how to use the various computer systems and collaborate with other units at the FAC. "Although much of the process was described ahead of time, the most valuable training occurred when we got there." Eighty-one percent of volunteers felt that the on-site training was helpful.

Many suggested that additional information regarding available resources, the overall FAC process, better-defined tasks, and experiences of past volunteers would have enhanced volunteers' understanding of their role. Forty-six percent indicated that there was a need for additional training on the molecular aspects of kinship analysis. Many volunteers reported that background information addressing the local culture and history should be included in training for future mass fatality kinship identification efforts. Ninety percent of respondents indicated that the tour of New Orleans helped to provide insight into the significance of their involvement in the recovery efforts. "The tour really helped motivate me to try calling people who we had been unable to contact in the past. Most people still couldn't be found, but it made finding even a few worthwhile."

\section{Logistics}

Over half of volunteers were recruited via the National Society of Genetic Counselors listserv and 37\% through word of mouth. Eighty-four percent of respondents indicated that their institutions supported their volunteer efforts. Fifty-two percent of genetics professionals were granted paid time off to volunteer at the FAC. Having a coordinator responsible for providing logistical support for volunteers, to arrange hotels and transportation, reduced the stress of traveling and taking time off from work. Specifically, respondents noted that assistance with travel arrangements (55\%), reimbursement for associated expenses (52\%), and training and support from the organization coordinating the identification process $(76 \%)$ played an important role in enabling them to volunteer.

\section{Skill utilization}

Many volunteers reported that they spent more time than expected "tracking down individuals through people search tools." As a result, much of what was accomplished was locating individuals who had been reported missing, not identifying bodies through kinship identification. "The experience was tremendously rewarding and interesting, even if I really didn't use my genetics knowledge that much." Some felt that the expectations needed to be clearer. As one volunteer stated, "I thought I'd be more involved in explaining DNA testing to relatives. In actuality, I was more involved in trying to locate missing persons." Only half $(50 \%)$ of the volunteers felt their genetics skills were adequately used and $68.2 \%$ would have liked to use more of their genetics/scientific knowledge. Other FAC volunteers noted that their clinical skills for "giving bad news" were useful when calling the family members of missing individuals who often needed grief and crisis counseling. However, $48.5 \%$ would have liked to use more of their psychosocial skills.

Most $(90.9 \%)$ volunteers were comfortable with the workload overall. Aside from the psychosocial and scientific skills that genetics professionals have, volunteers noted that it was useful to be a "self-starter and a problem solver," as resourcefulness in tracking down individuals led to increased success.

\section{Emotional response}

Based upon survey results, genetics professionals were capable of handling the emotional stress of volunteering at the FAC, with only $21 \%$ of respondents indicating that the experience was stressful. As one volunteer said, "I did cry. I did talk with the chaplain. I was glad to be there with a coworker to share the experience and to talk with when we returned. It was hard to put in words what we did and explain to others." Eighty percent felt that there was sufficient emotional support present at the FAC, including chaplains, meditation, massage, refreshments, and team building activities.

\section{Overall experience (Table 3)}

Overall, genetics professionals reported that volunteering at the FAC was a rewarding experience. "It was a very rewarding experience; one of the highlights of my career as a genetic counselor." Almost all (96.9\%) volunteers were satisfied with their experience at FAC. "What a rewarding experience personally and professionally. I would without hesitation be available for a future effort."

\section{Future directions}

Most (97\%) reported that they like to see the genetics community and professional genetics societies actively involved in further developing the role of genetics professionals in mass fatality response. All respondents $(100 \%)$ expressed interest in volunteering in future identification efforts.

\section{DISCUSSION}

After Hurricane Katrina struck New Orleans, leaving many deaths in its wake, immediate support for traditional victim identification methods was available. However, it was not until approximately 3 months later that the funding for DNA testing was authorized for victim identification. ${ }^{1}$ Understandably, families were very frustrated. The goal of the DNA identification effort was to perform accurate and timely identifications of all possible victims. To meet this goal, it was imperative that the 
Table 3 Overall experience and future directions

\begin{tabular}{|c|c|}
\hline & $\begin{array}{l}\text { Percent of respondents who } \\
\text { agree or strongly agree }\end{array}$ \\
\hline $\begin{array}{l}\text { Overall, the experience working at the } \\
\text { FAC was a positive one }\end{array}$ & 96.9 \\
\hline $\begin{array}{l}\text { I gained valuable experience from } \\
\text { volunteering at the FAC }\end{array}$ & 97.0 \\
\hline $\begin{array}{l}\text { I would have liked to receive updates } \\
\text { on the identification efforts }\end{array}$ & 95.5 \\
\hline $\begin{array}{l}\text { I would be interested in participating } \\
\text { in training modules that prepare } \\
\text { genetics professionals for future } \\
\text { mass fatality kinship identification } \\
\text { efforts }\end{array}$ & 80.3 \\
\hline $\begin{array}{l}\text { The genetics community should take } \\
\text { an active role in establishing its } \\
\text { role in mass fatality kinship DNA } \\
\text { identification }\end{array}$ & 95.4 \\
\hline $\begin{array}{l}\text { I would like to see my professional } \\
\text { organization (NSGC, ACMG, } \\
\text { ASHG, etc.) become involved in } \\
\text { developing the role of genetics } \\
\text { professionals in future mass fatality } \\
\text { recovery efforts }\end{array}$ & 97.0 \\
\hline $\begin{array}{l}\text { After returning from the FAC, I } \\
\text { wanted to be involved in } \\
\text { developing the role of genetics } \\
\text { professionals in future mass fatality } \\
\text { DNA identification efforts }\end{array}$ & 68.2 \\
\hline $\begin{array}{l}\text { I would be interested in volunteering } \\
\text { for future mass fatality DNA } \\
\text { identification efforts }\end{array}$ & 100.0 \\
\hline
\end{tabular}

DNA cases were identified and appropriate DNA reference samples identified and collected to allow kinship identification. Collecting and testing samples from individuals whose family members were missing but alive would preclude the testing of all samples that truly needed to be tested to identify a body in the morgue.

In a first of its kind, genetics professionals were asked to participate by identifying the reported missing cases that needed to be tested with DNA and generating a pedigree so that the appropriate family DNA references could be collected. In addition to performing this function, the genetics professionals performed two additional tasks critical to the success of the identification effort: (1) they located and reunited individuals who were alive but had not been located by their families and (2) they managed the expectations of the family and friends of missing individuals.

The involvement of genetics professionals in the DNA identification efforts after Hurricane Katrina represents a new intersection of genetics and forensics. The efforts were tremendously successful in supporting the reduction of reported missing by
99\% and issuing 153 DNA identification reports. ${ }^{1}$ As these survey results indicate, volunteers in this new area at the crossroads of genetics and forensics found the experience worthwhile and expressed their interest in learning more and participating in future efforts. As one example of further participation, Donkervoort et al. ${ }^{4}$ undertook an analysis of the accuracy in completion of the data collection form used after Katrina and suggested improvements to enhance accurate data collection with future use of this form. In addition, volunteers have suggested developing comprehensive training modules aimed at training first responders in collection of family history data and creating brochures or flowsheets outlining steps in obtaining accurate pedigree information.

The survey data presented here indicate a great interest in further developing the role of the genetics professional as part of the multidisciplinary identification teams that will be ready to assist after future mass fatalities. Given the need for and interest from the genetics community, the development of a registry of genetics professionals "ready to respond" should be explored. The components of the registry might include: (1) a voluntary registry of genetics professionals who would be willing to volunteer; (2) online training modules tailored to genetics professionals to introduce them to the associated forensics issues; (3) periodic updates about advances in forensic DNA identification issues; and (4) public service awareness efforts so that local officials who are responsible for mass fatalities can easily obtain access to the registry.

The nation would greatly benefit from having genetics professionals trained to respond after a mass fatality to provide support to local and/or state DNA laboratories tasked with the DNA identification efforts. As demonstrated in this survey, the professionals found the experience deeply rewarding and are committed to continuing involvement. Although more research and discussion are needed to explore the emerging role of genetics professionals in domestic and international emergency preparedness and forensic DNA identification with a focus on the ethical, legal and political issues involved, creating a registry is a practical first step.

\section{ACKNOWLEDGMENTS}

The authors thank Joan Bailey-Wilson, Barbara Biesecker, and Lisa Forman Neal of National Institutes of Health, Elizabeth Pugh of Johns Hopkins University, Rachel Grob and Susan Guma of Sarah Lawrence College, and Arbie Goings of the Family Assistance Center, for assistance with this work.

\section{REFERENCES}

1. Reuniting the Families of Katrina and Rita: Louisiana Family Assistance Center. Available at: http://www.dhh.louisiana.gov/offices/publications pubs-303/Full\%20Report.pdf. Accessed January 24, 2009.

2. Biesecker LG, Bailey-Wilson JE, Ballantyne J, et al. Epidemiology. DNA Identifications after the 9/11 World Trade Center Attack. Science 2005;310: 1122-1123.

3. Prinz M, Carracedo A, Mayr WR, et al. DNA Commission of the International Society for Forensic Genetics (ISFG): recommendations regarding the role of forensic genetics for disaster victim identification (DVI). Forensic Sci Int Genet 2007;1:3-12.

4. Donkervoort S, Dolan SM, Beckwith M, Northrup TP, Sozer A. Enhancing accurate data collection in mass fatality kinship identifications: Lessons learned from Hurricane Katrina. Forensic Sci Int: Genet 2008;2:354-362. 